\title{
MITIGATION SCENARIOS FOR RESIDENTIAL FIRES IN DENSELY POPULATED URBAN SETTLEMENTS IN SUKAHAJI VILLAGE, BANDUNG CITY
}

\author{
S. A. H. Sagala a , P. Adhitama ' , D. G. Sianturi ' , U. Al-Faruq ${ }^{\text {b }}$ \\ a Bandung Institute of Technology, Indonesia \\ ${ }^{b}$ Resilience Development Initiative, Bandung, Indonesia \\ c Perumnas, Indonesia
}

\section{Article Info:}

Received: 26 February 2016

in revised form: 10 September 2016

Accepted: 01 October 2016

Available Online: 31 October 2016

\section{Keywords:}

Fires, densely populated areas, urban risk, mitigation scenario

\section{Corresponding Author:}

Saut Aritua Hasiholan Sagala Bandung Institute of Technology,

Indonesia

Email: saut.sagala@gmail.com

\begin{abstract}
Residential fires are a form of disaster that often occurs in urban areas especially in densely populated settlements. This study looks at possible mitigation scenarios for this kind of disaster. A case study was conducted in Babakan Ciparay SubDistrict in Bandung City, among the densely populated settlements, and was focused especially on Sukahaji Village, a sub-unit of Babakan Ciparay, which is the most densely populated village in Bandung City with up to 234.14 people/ha. There have been six structural fires recorded from 2007 until 2010 occurring in Sukahaji. This study applied stratified random sampling as the preferred sampling technique and data collection method from a total population of 3,227 buildings. The data was then examined using risk analysis. The results have led to two intervention measures suggested as mitigation scenarios for residential fires that can be applied within the Sukahaji Village. The study concludes that mitigation measures through strengthening community capacity can be the principal option in reducing risk to fires in densely populated urban settlements.
\end{abstract}

\section{INTRODUCTION}

Fires in urban areas often break out in densely populated residential areas. The source of the fire hazard is often caused by careless residents during daily activities such as smoking, cooking, use of electronic equipment, playing with live fire, and gas leaks. Besides, fires can as well be caused by natural incidents such as lightning, earthquakes (rupturing gas pipes), volcanic eruptions, and drought (Indonesian Government, 2007). Sagala et al. (2014) observed that community's behavior related to residential fires is unsafe. It involves fire related activities, which are often conducted along with other activities.

According to the IFRC (2010), densely populated residential areas are vulnerable to disasters, especially fires. Bandung is a city with high population density with up to $16,008.53$ people $/ \mathrm{km}^{2}$ or roughly 160.0853 people/ha (Bandung Central Bureau of Statistics, 2009). In the recent study by Tarigan et al. (2016), Bandung has grown as one of the important metropolitan areas in Indonesia.

Huang (2009) argued that some of the most loss-inflicting fires are the ones that occurred in urban/residential areas. In addition to that, Xin and Huang (2013) studied the model reporting the relation between losses of lives, per $\mathrm{m}^{2}$ annually. The inappropriate set up of billboards on exterior walls on the building could potentially trigger fires and accelerate fire spreading (Zhou, 2013). Therefore, the general relationship between urban planning and the incident of urban fire exist. As stated by the Fire Prevention and Mitigation Agency of Bandung, urban fires occur most often in areas with a high population density.

In general, the data from Local Disaster Management Agency (BPBD) show that during ten years (20002010), 1,624 fires broke out with around 773 incidents (48\%) taking place in residential areas. The average 
number of fire incidents in Bandung sums up to 162 incidents per year with the material loss going up to IDR 21,137,813,636 each year (BPBD Bandung, 2016). Table 1 shows the high rate of urban fires and the huge loss-inflicting on Bandung.

Table 1. Total loss and fire incidents in Bandung City (BPBD Bandung, 2016)

\begin{tabular}{|rrrrr|}
\hline Year & Total No. of Incidents & \multicolumn{1}{r}{ Fatalities } & Non-fatal Casualties & Approximate Loss (Rupiah-IDR) \\
\hline $\mathbf{2 0 0 0}$ & 180 & 6 & 5 & $18,874,700,000$ \\
\hline $\mathbf{2 0 0 1}$ & 167 & 2 & 10 & $74,557,150,000$ \\
\hline $\mathbf{2 0 0 2}$ & 207 & 4 & 22 & $20,464,050,000$ \\
\hline $\mathbf{2 0 0 3}$ & 157 & 4 & 9 & $10,883,600,000$ \\
\hline $\mathbf{2 0 0 4}$ & 173 & 4 & 3 & $13,880,300,000$ \\
\hline $\mathbf{2 0 0 5}$ & 134 & 10 & 12 & $17,771,000,000$ \\
\hline $\mathbf{2 0 0 6}$ & 123 & 3 & 3 & $11,041,750,000$ \\
\hline $\mathbf{2 0 0 7}$ & 160 & 3 & 10 & $36,521,500,000$ \\
\hline $\mathbf{2 0 0 8}$ & 141 & 1 & 8 & $12,235,700,000$ \\
\hline $\mathbf{2 0 0 9}$ & 121 & 4 & 9 & $9,801,200,000$ \\
\hline $\mathbf{2 0 1 0}$ & 61 & 0 & 2 & $6,485,000,000$ \\
\hline $\mathbf{2 0 1 1}$ & 124 & $\mathrm{Na}$ & $\mathrm{Na}$ & $\mathrm{Na}$ \\
\hline $\mathbf{2 0 1 2}$ & 136 & $\mathrm{Na}$ & $\mathrm{Na}$ & $\mathrm{Na}$ \\
\hline $\mathbf{2 0 1 3}$ & 131 & $\mathrm{Na}$ & $\mathrm{Na}$ & $\mathrm{Na}$ \\
\hline $\mathbf{2 0 1 4}$ & 162 & $\mathrm{Na}$ & $\mathrm{Na}$ & $\mathrm{Na}$ \\
\hline $\mathbf{2 0 1 5}$ & 177 & $\mathrm{Na}$ & 93 & $\mathrm{Na}$ \\
\hline Total & 41 & & $232,515,950,000$ \\
\hline
\end{tabular}

Table 1 provides data on the total number of incidents and also the approximate loss Bandung sustained due to residential fires during 2000-2010. The economic loss hit the highest number in 2001 with damages amounting up to IDR $74,557,150,000$. Out of all these occurrences, the majority of them took place in residential buildings. This information is presented in Figure 1.

Figure 1. Fire incidents in Bandung City years 2000-2010 (BPBD Bandung, 2016)

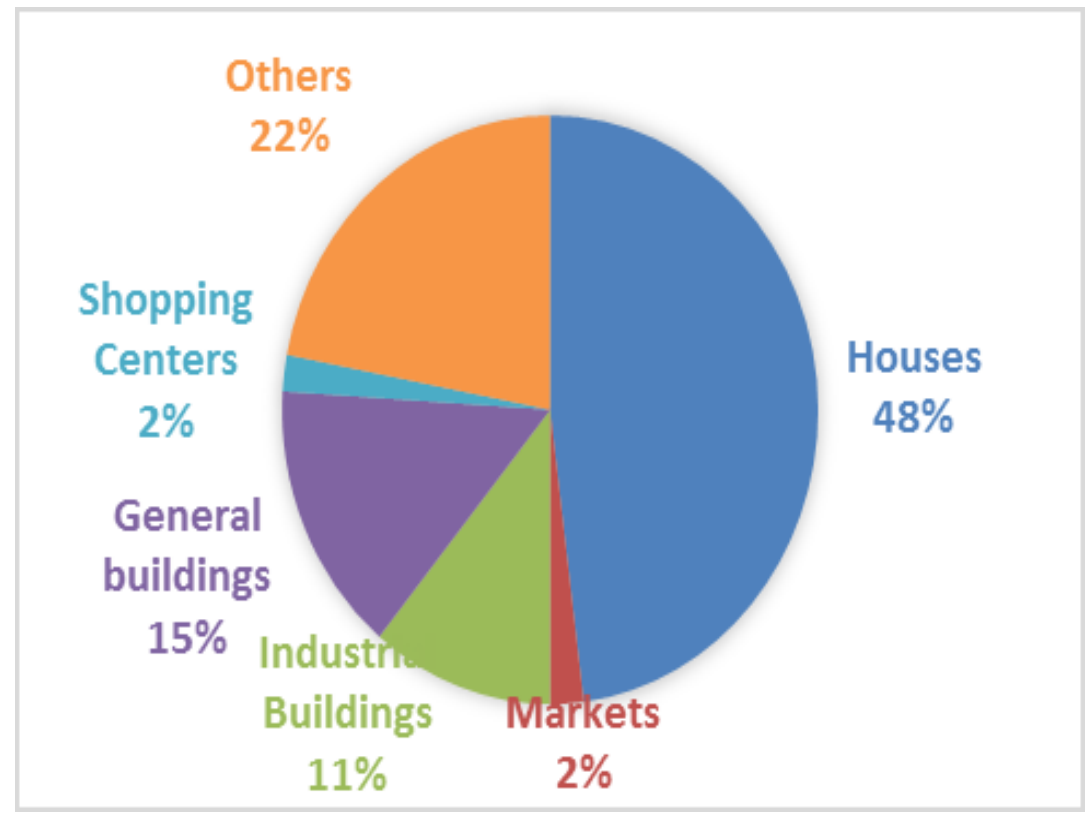


Babakan Ciparay (Figure 2) stands out as one of Bandung's sub-districts with the highest number of fire incidents from 2007-2010, with 34 occurrences within that timeframe. It is exacerbated by the fact that Babakan Ciparay Sub-District has the highest population than any other districts in Bandung with 144,892 residents (Bandung Central Bureau of Statistics, 2009). Spreading up to 745 ha, Babakan Ciparay is the densest populated district; approximately $19,448.59$ people within each square kilometer, making it a vulnerable target to fires. In total, six villages make up Babakan Ciparay Sub-District, where Sukahaji Village proves to be the densest populated measuring up 234.14 people/ha.

From recorded incidents, it is known that six of them occurred within the houses of Sukahaji in 20072010. Based on this fact, Sukahaji is used as a case study in this work. The study will focus on Sukahaji's Neighborhood Unit (RW) 01- 04 to be more detailed and rigorous. This study aims to develop proper mitigation scenarios feasible to be applied in Sukahaji Village. Fire mitigation scenarios are required by the Indonesian Law no. 24/2007 - a law on disaster mitigation - as a form of disaster risk reduction measure. Furthermore, the integration between development programs and risk reduction is also mandated by the Law.

Figure 2. Map of the study area (Authors, 2016)

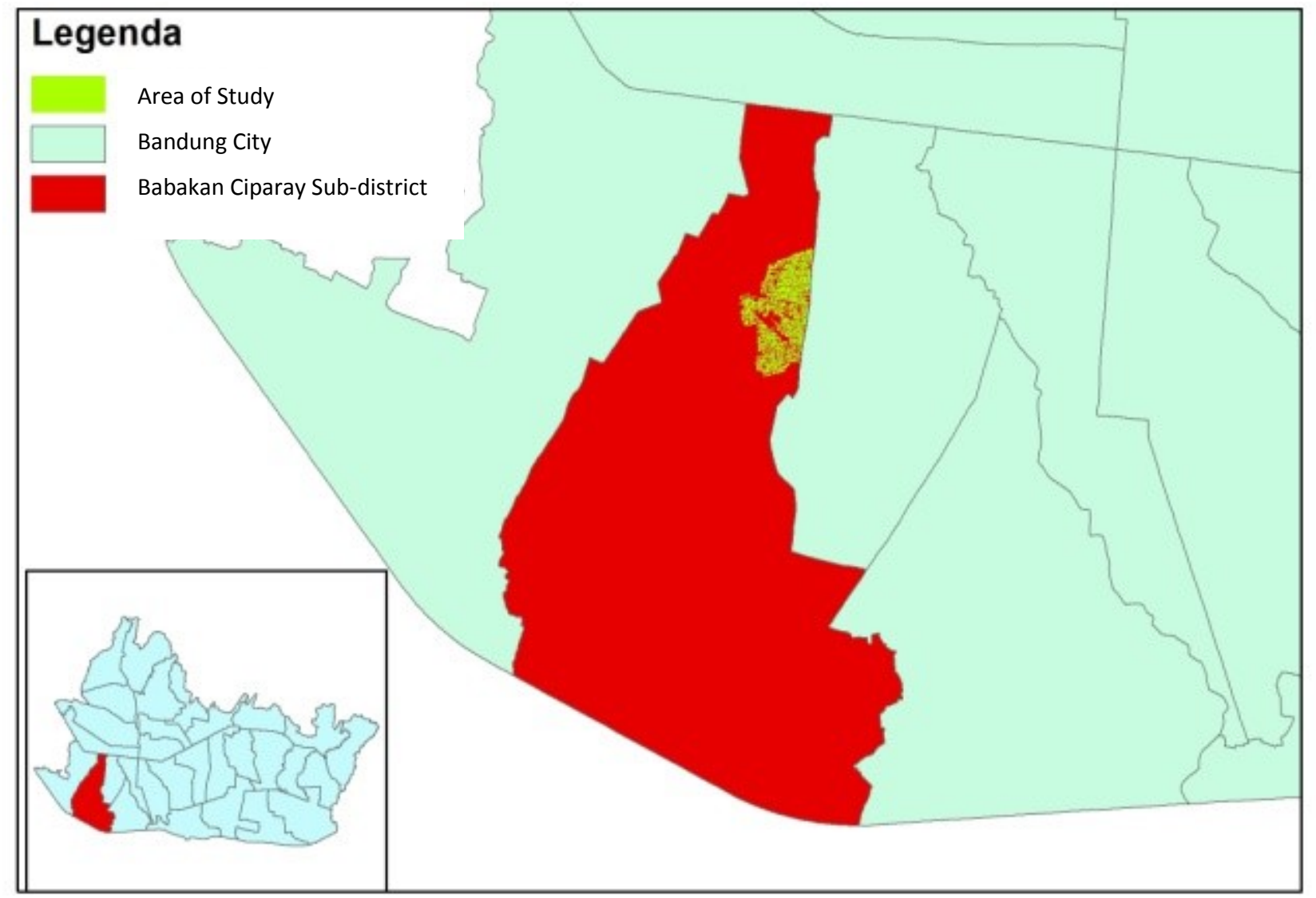

Some of studies on residential fires in densely populated settlements have been previously conducted. Prathama (2011) and Dwijayanti (2008) carried out research of urban fires within Bandung City but omitted Geographical Information Systems (GIS) as a tool of analysis. The use of GIS in disaster studies is expected to boost the accuracy in which the study is conducted and also the mitigation measures produced by the study. Wahyudi (2004), on the other hand, utilized GIS but the area of study was too large and resulted in homogenous risk analysis for each type of land use. Thus, it was not able to create any mitigation measures for a smaller area of study. This study aims to fill in the gap where GIS is used to analyze fire risk in detail and a smaller area of study. This article will conduct a more detailed discussion using individual buildings from neighborhood sub-units (RT) as a basis variable for analysis (focused on Neighborhood Unit 01-04 of Sukahaji Village). The result will be a more detailed analysis of the area of study thus producing more 
specific mitigation measures. This study on densely populated settlements may be replicated, or at least referred to, by other residential areas. In more concrete applications, the results of this study could be implemented in the designing of Detailed Spatial Plans (RDTR) and Building and Environmental Plans (RTBL) as additional material. Eventually, future spatial plans will take into account the disaster aspect of the built environment, especially residential fires and other fire disasters.

At the outset, this article will examine urban and residential fires in Bandung City, particularly within Sukahaji Village, and the facts surrounding the incidents. The next part will present a literature review based on other studies that have been conducted before discussing fires and fire mitigation in urban areas. The third part will explain the methodology used in this study, followed by the fourth part providing possible mitigation scenarios to be carried out based on previous risk analyses of Sukahaji Village. The fifth and final part will present the conclusion and also recommendations which will expectantly serve as input for decision makers in fire risk reduction efforts in Sukahaji Village.

\section{DATA AND METHODS}

This section consists of two parts. The first explains the components of a fire hazard that will be used in the analysis. The second part discusses data surrounding vulnerability. In general, this study calculates and analyzes all parts of the study area. A total of 3,227 building units were analyzed through a sample of 882 units taken using stratified random sampling. The units analyzed include houses, shops, as well as vacant lots. Hazard components were analyzed based on the density of the buildings and activities involving fires where each building has the potential to be the cause of a fire for using fires while cooking, doing household activities, or conducting industrial processes.

\subsection{Hazard}

In the study area, the hazard component consists of liquefied petroleum gas/gas tank (LPG) warehouses, household and industrial activities, and building density. According to Suprapto (2008), fires are flames ignited and spread without deliberation. Fires break out when objects catched by fire go out of control and pose a threat to people and properties. A fire incident usually goes through a certain process before being put out. Mantra (2005) explains that the process of developing a fire is as follows:

a) Ignition

This is marked by a small fire caught by an object in a certain space/room caused by heat energy.

b) Growth

Fire grows and spreads depending on how much fuel or flammable materials are nearby-a fuelcontrolled fire. At this point, evacuation is highly recommended during 3-5 minutes before flashover.

c) Flashover

A transition period where the whole room is ignited before engulfed in flames. This phase happens rapidly with temperatures going from $300^{\circ} \mathrm{C}$ up to $600^{\circ} \mathrm{C}$.

d) Fully developed

When it is no longer 'a fire in a room' rather 'a room on fire', the whole room is on fire and the room is fully involved. The temperature may reach $1200^{\circ} \mathrm{C}$.

\section{e) Decay stage}

Fire starts to decay when materials serving as fuel have all been burned out decreasing temperature and slowing the rate of the fire.

Sources of fire hazards in residential areas are usually neglecting activities such as smoking, cooking, use of electronics, playing with fire, gas leaks, etc. (Huang, 2009). Fire development is significantly affected by the availability of fuel and combustible materials in the course of the fire. In residential areas, building materials usually become sources of fire; the more materials there are the bigger the fire there will be. To mitigate fire hazards, the time of ignition and size of fire needs to be identified in order to subdue the fire 
before it consumes all the combustible materials in its path. During a developing fire, it is optimal to extinguish it before the flashover phase (Mantra, 2005).

According to Barnwell et al. (2005), fire hazards are often connected to fire exposure. In fire science terminology, fire hazards can explain the potential intensity of fires. The term shows the differing intensities of fires, and there needs to be a classification of sources of hazards based on potential intensities that will affect the size of the fire.

Fire risk is the probability of a fire igniting that has the potential to injure persons and damage private property. The bigger the fire the more damage it causes. Huang (2009) argued that the number of fire incidents in residential areas including its population and building characteristics are connected. The majority of incidents can be linked to human behavior and personal routines. This is supported by Kai Huang's research in 2009 that stated that human behavior is the number one cause of residential fires.

\subsection{Fire Mitigation in Urban Areas}

According to Cova (1999) disaster mitigation forms a part of disaster mitigation. Mitigation is an effort to reduce or eliminate the possibility and/or consequences of hazards. Mitigation is carried out to treat hazards in such a way that its effects on society is importantly reduced. Coburn et al. (1994) explain that the protection from disaster hazards can be achieved by eliminating the causes of said hazards (reducing the risk) or by reducing the effects of hazards when they appear (reducing vulnerability or increasing the potential capacity of elements at risk).

Moga (2002) describe that mitigation planning is the developing of strategies to reduce the impacts of disaster on communities, facilities, rural and urban areas, or countries. Mitigation planning can be categorized into many groups, most commonly into structural mitigation and non-structural mitigation (Moga, 2002). Five types of basic measures that can be used in mitigation planning programs are as follow: engineering and construction measures, physical planning measures, economic measures, institutional and management measures, and community action (Coburn et al., 1994).

Mitigation measures aim to not only prevent loss of human lives and lessen financial loss but also decrease adverse effects on socio-economic activities caused by disasters. If sources of mitigation are limited, mitigation measures can be targeted towards the most effective element that significantly influences community activity. Vulnerability assessments are an important aspect of an effective mitigation planning. Vulnerability covers, but is not limited to, risk of physical damage, economic loss, and the lack of resources to recover from disasters.

Moreover, Coburn et al. (1994) stated that disaster mitigation measures can be grouped into either passive or active mitigations. Passive mitigation measures are carried out through control or penalties to prevent undesired actions such as land use control, mandatory insurance, etc. Active mitigation measures are taken to promote desired measures through incentives such as building material subsidies, education and training, etc.

There are countless of ways to carry out fire mitigation measures in order to increase house safety, especially from combustible materials, installing smoke detectors (Duncanson et al., 2002). Installing smoke detectors is an easy and effective method that serves as a warning system in the case of a fire (Duncanson et al., 2002). Community participation is an important component in reducing the number of fire incidents. Educating the community is extremely important strategy to prepare them to take appropriate measures in the event of a fire (Duncanson et al., 2002).

\subsubsection{Building Density}

Table 2 shows that RW 03 has far more people living in it than others. Building density can be calculated by comparing the area of each building with each parcel/block of land. The analysis showed that the study area has a building density of about $55.24 \%-85.31 \%$, which falls under the category of medium to high density (Rianta, 2007). 
Table 2. Demographic characteristics in Sukahaji Village (Sukahaji Village, 2011)

\begin{tabular}{|cc|}
\hline RW & Population \\
\hline $\mathbf{0 1}$ & 4,127 \\
\hline $\mathbf{0 3}$ & 4,271 \\
\hline $\mathbf{0 4}$ & 5,649 \\
\hline
\end{tabular}

\subsubsection{Distribution of LPG Warehouses and Tofu Industries}

LPG warehouses and tofu industries/factories are apparent sources of fire hazards in Sukahaji Village. Other sources include residential buildings that are too close to each other and made of flammable materials. The Table 3 below showcases the fact that RW 03 poses the greatest risk having two tofu factories than other RWs.

Table 3. Distribution of LPG warehouses and tofu industries (Sukahaji Village, 2011)

\begin{tabular}{|c|c|c|c|c|}
\hline No & Building & RT & RW & Unit(s) \\
\hline 1 & LPG warehouse & 02 & 02 & 3 \\
\hline \multirow{5}{*}{2} & \multirow{5}{*}{ Tofu factory } & 02 & 03 & 1 \\
\hline & & 03 & 03 & 1 \\
\hline & & 04 & 03 & 2 \\
\hline & & 05 & 03 & 2 \\
\hline & & 05 & 04 & 1 \\
\hline
\end{tabular}

\subsubsection{Vulnerability}

In this study, analyses were carried out in numerous phases. General data such as population data, distribution of LPG warehouses, roof materials, wall materials, road width, and sources of water were used to give a broad picture of Sukahaji Village. These elements are considered as vulnerabilities for the residents include roof and wall materials in the buildings as well as road width and sources of water for better access for firefighters.

a. Roof and Wall Materials

Roof and wall materials are components used to conduct a fire risk analysis in Sukahaji Village. Based on observations done in the field, there are a number of materials used by residents in the study area including asbestos, plastic, rattan webbings, zinc, clay tiles, wood, cement, and a combination of bricks and cement. There were also buildings that utilized more than one type of materials for its roofing such as a combination of clay tiles and plastic, clay tiles with asbestos, clay tiles and zinc, and other combinations.

Table 4. Roof materials (Sukahaji Village, 2011)

\begin{tabular}{|llc|}
\hline Classification & Roof Type & $\begin{array}{c}\text { Number of } \\
\text { buildings using it }\end{array}$ \\
\hline $\begin{array}{l}\text { Fireproof } \\
\text { Easily } \\
\text { combustible }\end{array}$ & Cement, zinc, clay tiles and zinc, clay tiles & 665 \\
\hline $\begin{array}{l}\text { Not easily } \\
\text { combustible }\end{array}$ & $\begin{array}{l}\text { Plastic and zinc, bricks and cement, rattan webbings and zinc, clay tiles and } \\
\text { asbestos, clay tiles and plastic, plastic and zinc }\end{array}$ & 175 \\
\hline
\end{tabular}


Wall materials used by the locals moderately vary including rocks, cement, wood, rattan webbings, plywood, zinc sheets, plastic sheets, concrete, and glass. Houses using a combination of these materials equally existed. Tables $\mathbf{4}$ and $\mathbf{5}$ present in detail the material used by Sukahaji locals for their roofing and walls.

Table 5. Wall materials (Sukahaji Village, 2011)

\begin{tabular}{|lll}
\hline \multicolumn{1}{c}{ Classification } & \multicolumn{1}{c|}{ Type of Wall } & Buildings using it \\
\hline Fireproof & $\begin{array}{l}\text { Bricks; bricks and cement; bricks, cement, and ceramics; } \\
\text { bricks, cement, and zinc; concrete; glass; ceramics; } \\
\text { cement; zinc }\end{array}$ & 661 \\
\hline Not easily combustible & $\begin{array}{l}\text { Bricks; cement, bamboo; bricks, cement, and rattan } \\
\text { webbings; bricks, cement, and wood; bricks, cement, and } \\
\text { zinc sheets; bricks cement, and plywood; bricks, cement, } \\
\text { and plastic; wood and zinc }\end{array}$ & 48 \\
\hline Easily combustible & Rattan webbings; wood; wood and rattan webbings & 157 \\
\hline
\end{tabular}

\section{b. Road Width and Sources of Water}

Road width in the study area importantly vary ranging from local roads measuring $0.6 \mathrm{~m}$ up to secondary roads with $\pm 4 \mathrm{~m}$. Road width surrounding the area of study affect the accessibility of fire trucks in the event of a fire (Figure 3). The $3.5 \mathrm{~m}$ width for roads is minimum required for fire trucks to be able to pass through (Figure 4). There are only four roads (Babakan Ciparay Road, Terusan Pasir Koja Road, and two local roads) in the study area having the required width of more than $3.5 \mathrm{~m}$. These roads are already well paved made out of asphalt and are well maintained and can be used without obstruction by four-wheeled vehicles or fire trucks. The area surrounding these wide roads are within access of fire trucks, while as areas outside of the roads are not within reach of fire department services if any fire incident breaks out.

Figure 3. Wall Materials in the Sukahaji (Authors, 2016)

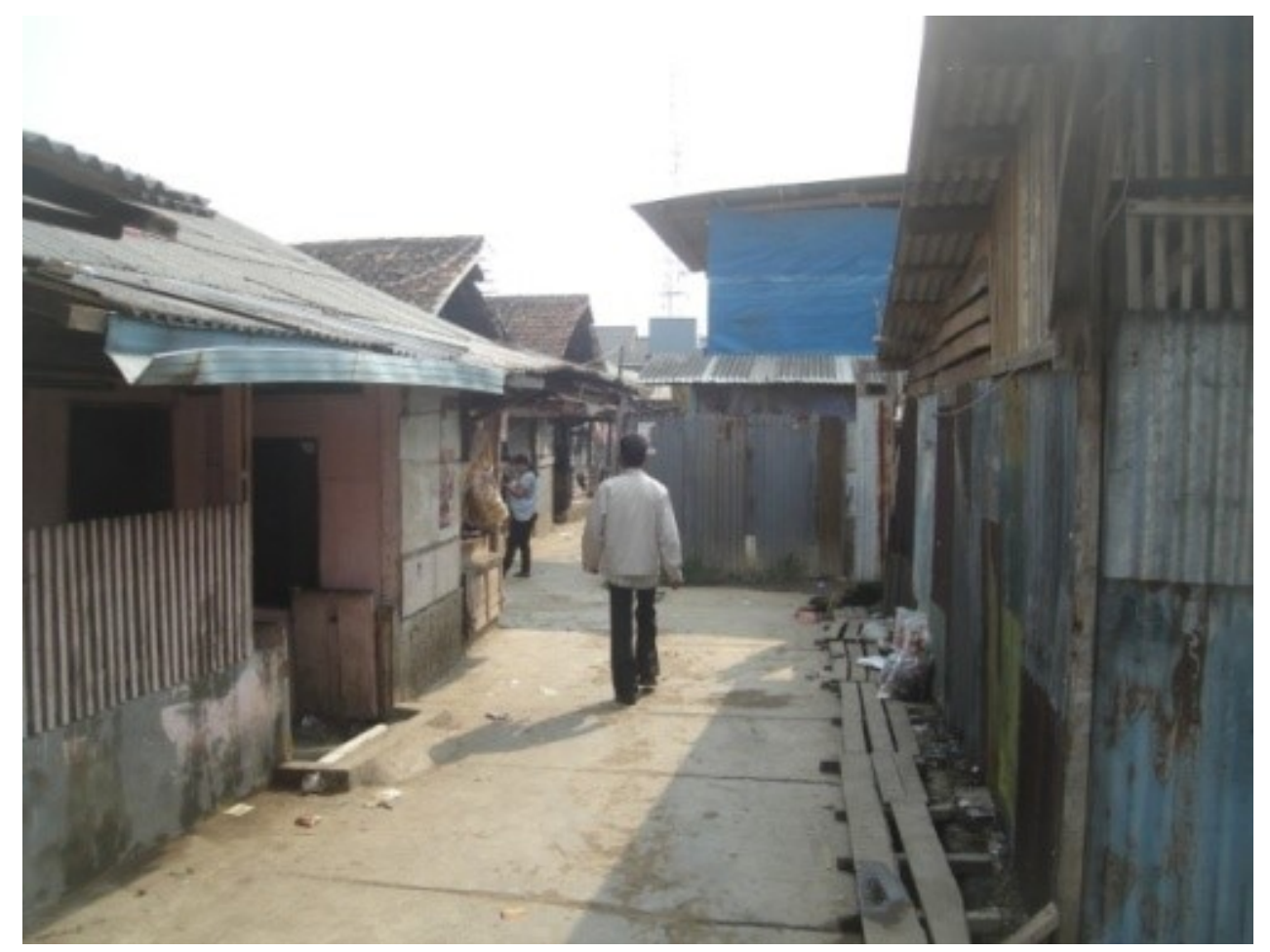


Figure 4. Road Width in the Sukahaji (Authors, 2016)

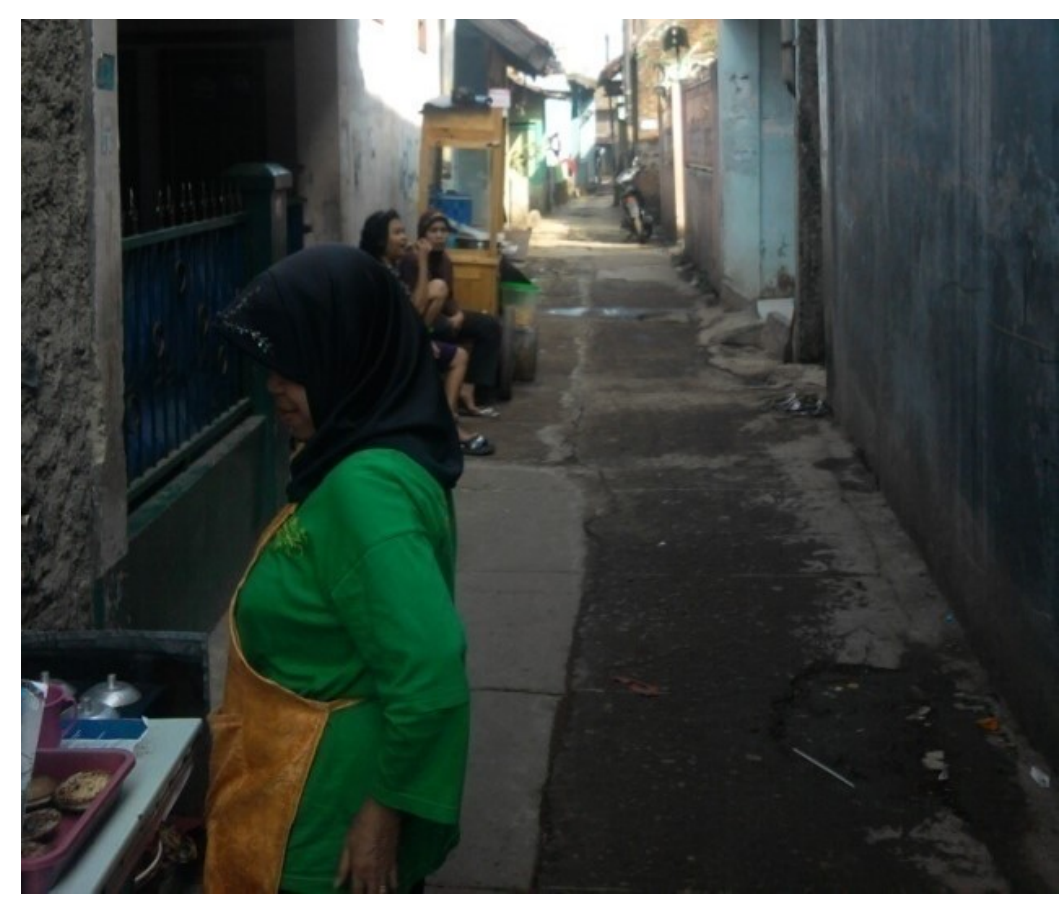

Sources of water within the study area include wells, the river, waters depots, and local pools/ponds (Figure 5). These sources will serve well in the process of extinguishing fires. Thirty-one wells with a total water volume of $118,338.8 \mathrm{~L}$ in the dry season is accessible. On average, a well has a volume of 4,000 L which has the same capacity as one fire truck. It can be used for fire extinguishing to control the flames before firefighters arrive.

In the area, a total of 10 water depots/water reservoirs with a volume $12,480 \mathrm{~L}$ is available. Since the primary source of water is the local water company (PDAM), the necessary amount of water for extinguishing fires is fulfilled. This particular source has been used to extinguish fire incidents in RT12, RW02 to compensate the fact that firefighters have very little access to the site of the fire. It is clear that water depots have been proved to be an effective alternative in extinguishing the fire.

Figure 5. River ponds/pools as a source of water (Authors, 2016)

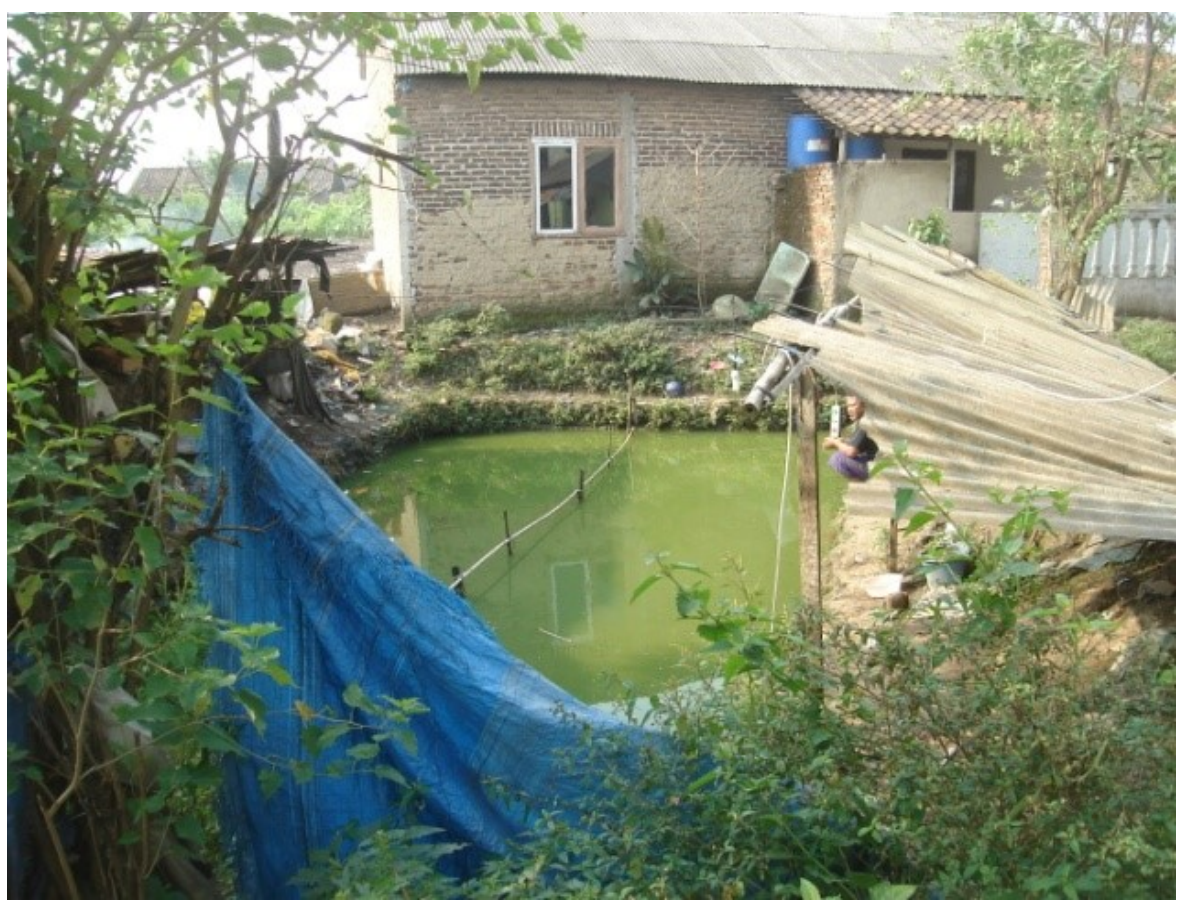


There are 8 ponds with a total volume of $148,000 \mathrm{~L}$, averaging $18,500 \mathrm{~L}$ each pond. This source of water can be effective in extinguishing fires as it can serve as a reservoir for fire trucks. There is a river that flows through the study area with a flow rate of $80 \mathrm{~L} / \mathrm{s}$ or equals to $24,000 / \mathrm{m}$. this source of water can be used to supply water to fire trucks and help in fire extinguishing efforts. Areas that have sources of water and can access them are said to be areas provided with a water source, while areas without a source of water are areas that are not provided with sources of water.

\section{c. Risks of Fires in Sukahaji Village}

Based on statistical data of Sukahaji Village, a fire risk map was created using GIS focusing on RWs 0104. An illustration of the spatial aspects of the risks is provided in Figure 6 . To determine the level of fire risk in Sukahaji Village, a classification was made based on fire risk analysis. This risk classification is relative to the area of study, meaning that it may not be suitable for other areas prone to fires. Nevertheless, this classification relative to the area can be used as a reference for deciding fire mitigation measures.

Figure 6. Map of fire risks in Sukahaji Village (Analysis, 2016)

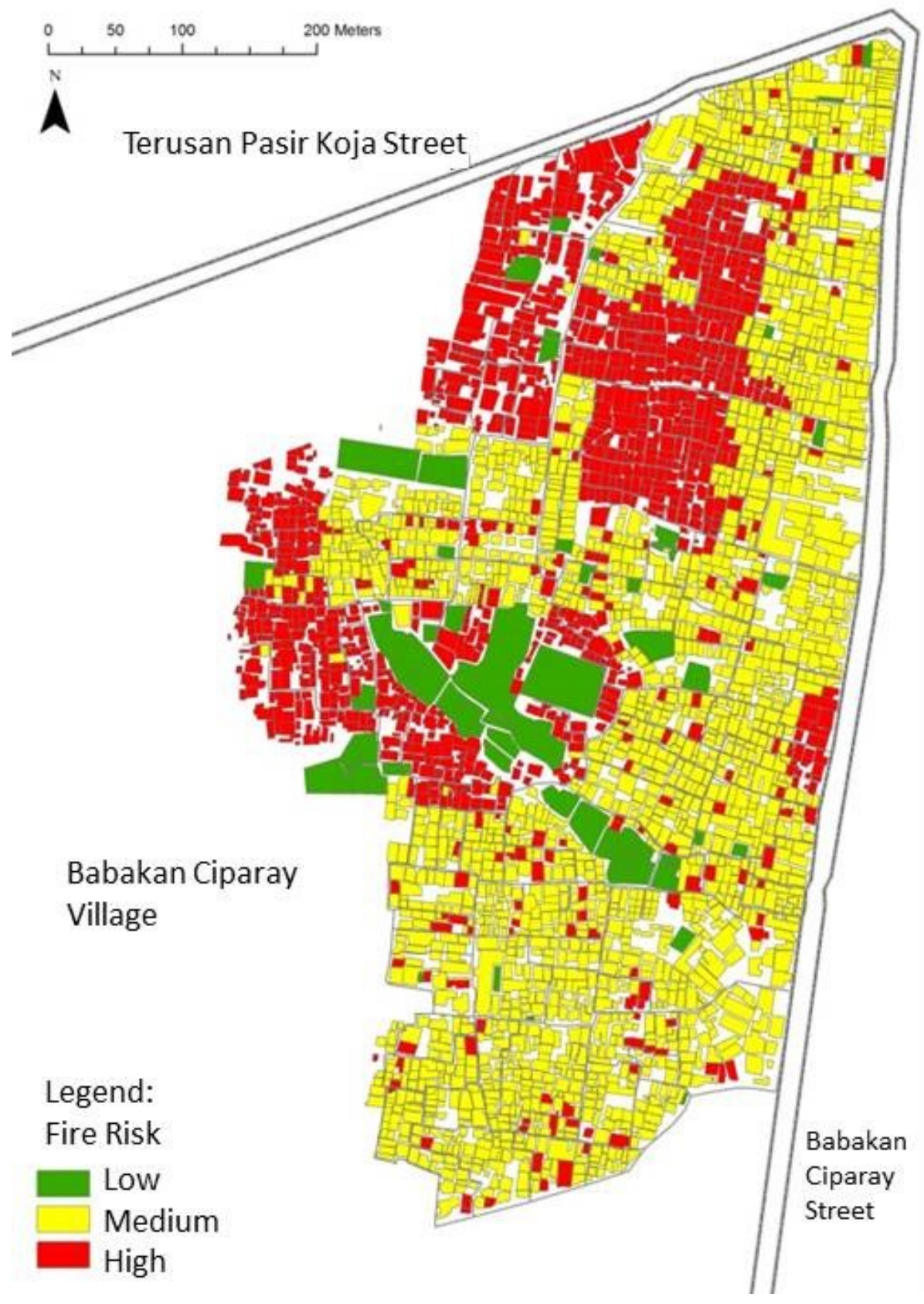


Buildings counted to have a High Risk of catching fire indicate its proximity to a source of hazard (LPG warehouse and tofu factory) and are made of not-easily-combustible building materials. Buildings classified as having a Medium Risk of catching fire indicates its proximity (not as close as before) to a source of hazard and are made of easily-combustible building materials. The last category classifies buildings with a Low Risk as buildings that are not in proximity to a source of hazard and are made of fireproof materials. It can also mean that these are open lots.

From the risk analysis, it has been found out that most of the study area is classified under Medium Risk, which is $61.17 \%$ of the total buildings (1,974 building units). The other 1,193 units are classified as having a High Risk, i.e. $36.97 \%$ of the total buildings. Unfortunately, only 60 buildings can be classified as Low Risk counting $1.86 \%$ of the total buildings.

\section{RESULTS AND DISCUSSION}

Based on the results of Sukahaji's risk analysis, numerous mitigation scenarios were produced. A comparison showing the different results of spatial risk calculations from the produced scenarios is presented in Figure 7. In general, two fire mitigation scenarios were made each one with a different intervention than the other. The first scenario will intervene by including capacity (C) variables in calculating fire risk. These variables are sources of water and road width adequate for fire trucks to pass through. From the risk analysis using capacity variables, it is discovered that the number of buildings categorized as having a High Risk is 262 units (8.12 \%). The number of buildings having a Medium Risk sums up to be 417 units $(12.92 \%)$, whereas buildings with a Low Risk goes up to 2548 units (78.92 \%). The second scenario is to intervene at the hazard $(\mathrm{H})$ component of the risk analysis. This hazard component consists of tofu factories and LPG warehouses as well as population density.

Based on the analysis, it is known that this mitigation measure has a significant impact on the study area. This impact can be observed by the decline of risk in the area that will affect the degree and the amount of damage and loss of private property as well as life. The risk analysis shows that a number of 805 units (23.94 \%) of buildings having High Risk, up to 2362 buildings having Medium Risk (73.19\%), and 805 units $(24.95 \%)$ having Low Risk. This section will discuss the findings resulted from the analysis. The figures 7-8 show the three scenarios in which different interventions are taken.

Mitigation scenarios can be carried out through approaches on capacity (C) and hazards ( $\mathrm{H})$. The first scenario can be done by intervening risk and taking into account the capacity variable. It can be accomplished by supplying and installing a water container constantly available for firefighters during fire extinguishing efforts. Improving road conditions is another way to facilitate maneuverability of fire trucks in the event of a fire.

As sources of water in the location, there should be water containers (for example 2 panel tanks with a capacity of $520 \mathrm{~L}$ each) equipped with wheels to help the locals transport the tanks to the location of the fire. These tanks should always be filled with water to be used in the case of a fire. Furthermore, identification markers for each tank are necessary to facilitate locals recognizing them as a source of water.

With these efforts, sources of water are expected to be easily accessed within Sukahaji. The roads reparation in the study area is suggested in order to facilitate fire trucks in the case of a fire. Moreover, certain important roads need to be expanded to increase maneuverability of the fire trucks. Total expansion of road is not possible due to the high building density in some areas. These rebuilding efforts should not cause damage to the surrounding villagers.

The second mitigation scenario can be carried out by alleviating the hazard $(\mathrm{H})$ variable through engineering and construction. This measure will separate or relocate sources of danger from populated areas. Household activities are part of these areas and cannot be moved. Instead, sources of danger, such as LPG warehouses and tofu factories, should be relocated. These sources of danger can be moved to their proper land uses. Form of law or regulation should be enforced to delineate the prohibition of industrial activities and storing flammable materials within residential areas. 
Figure 7. Comparing risks of numerous fire mitigation interventions (Analysis, 2016)

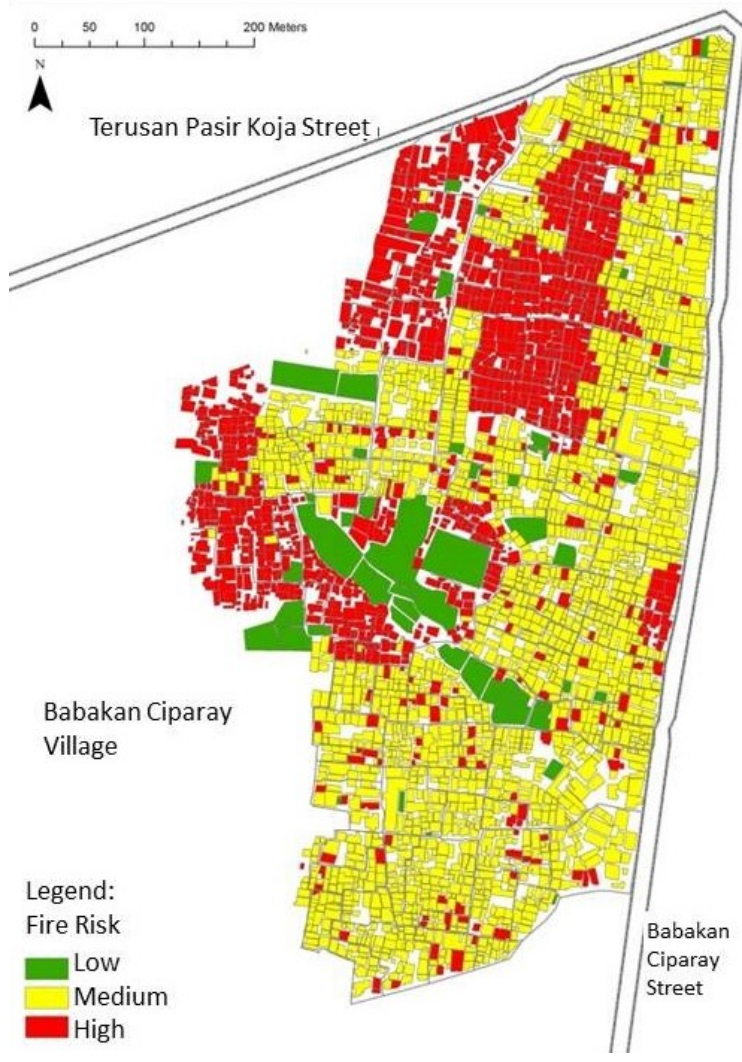

\section{No Intervention}

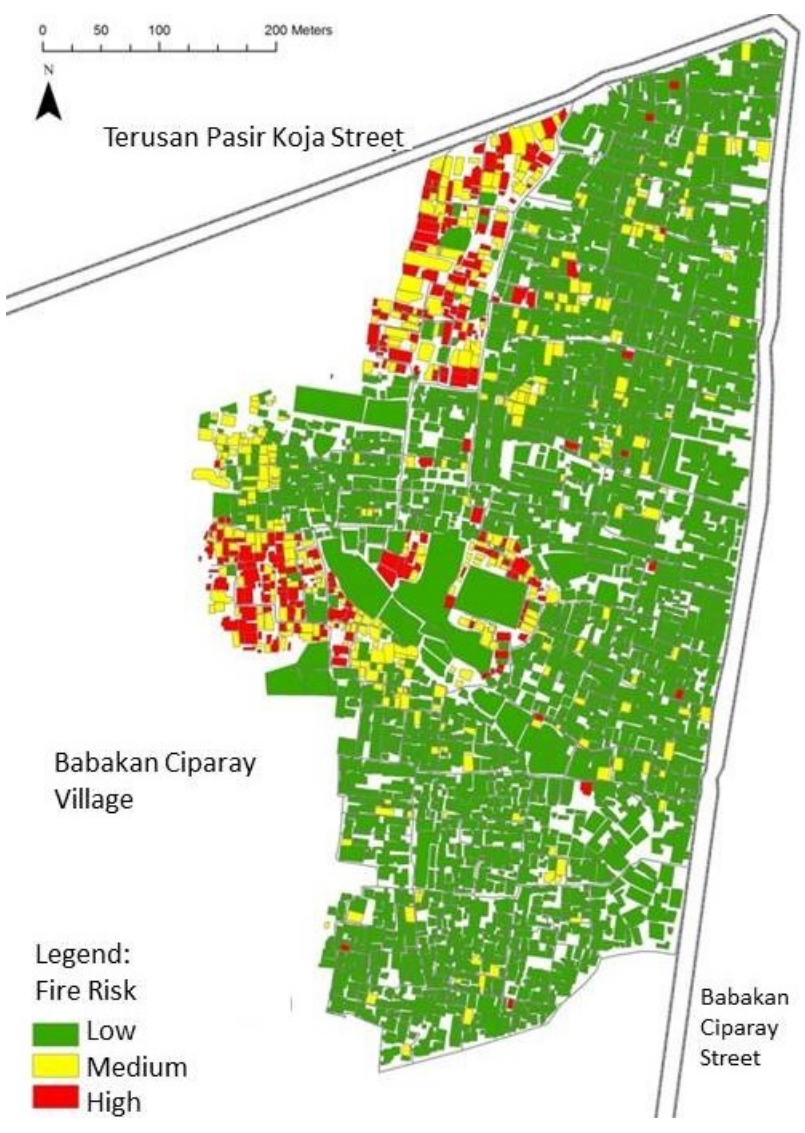

Intervention 1

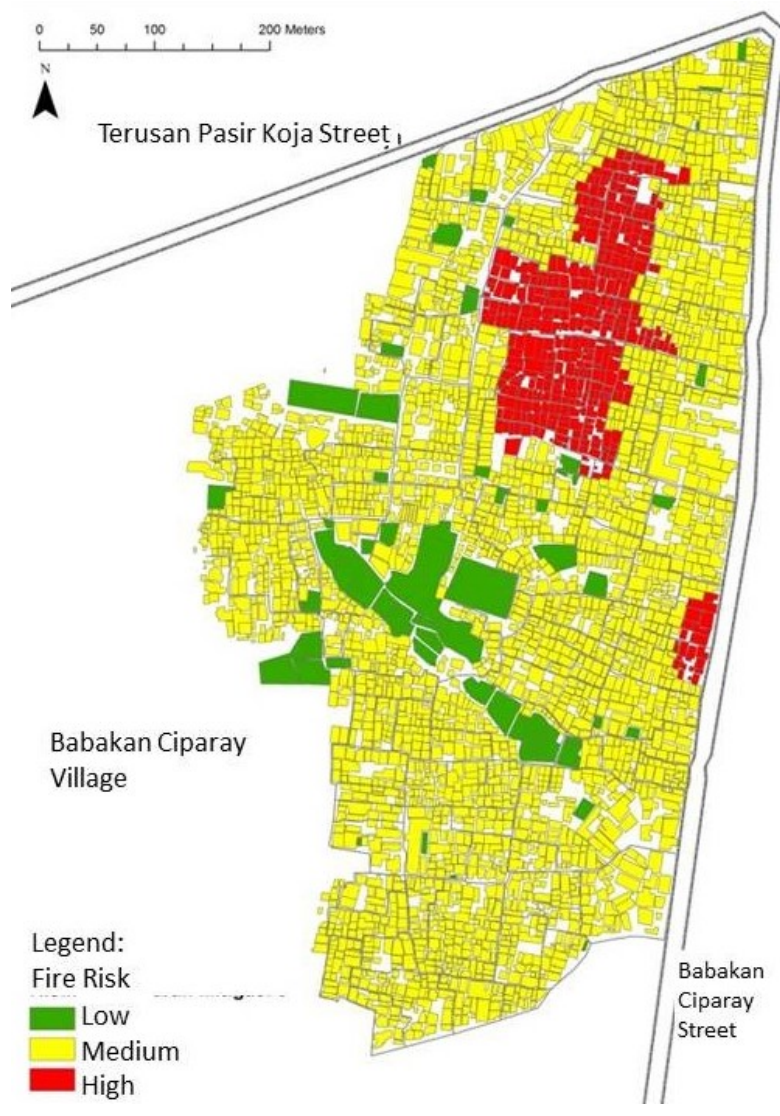

Intervention 2 
Effort to decrease the density of buildings within Sukahaji would be nearly impossible as there would be mass evictions and demolitions. There would also be issues of who would be evicted and whose house would be demolished. From the risk analysis and mitigation scenarios in the previous part, type of mitigation would have the most significant impact for number of units with a High Risk. A comparison between numbers of buildings with a High Risk after each mitigation scenario is illustrated in Figure 8.

From the graph below, it can be concluded that if the building materials are replaced with fire resistant ones (the first mitigation scenario), it will dramatically decrease the number of buildings with a High Risk. It is proven to be more effective than relocating LPG warehouses and tofu factories (the second intervention). Even then, optimal effort can be achieved if a combination of the first and second scenario can be executed in Sukahaji.

Figure 8. Number of buildings with a high risk after application of each mitigation scenario (Analysis, 2016)

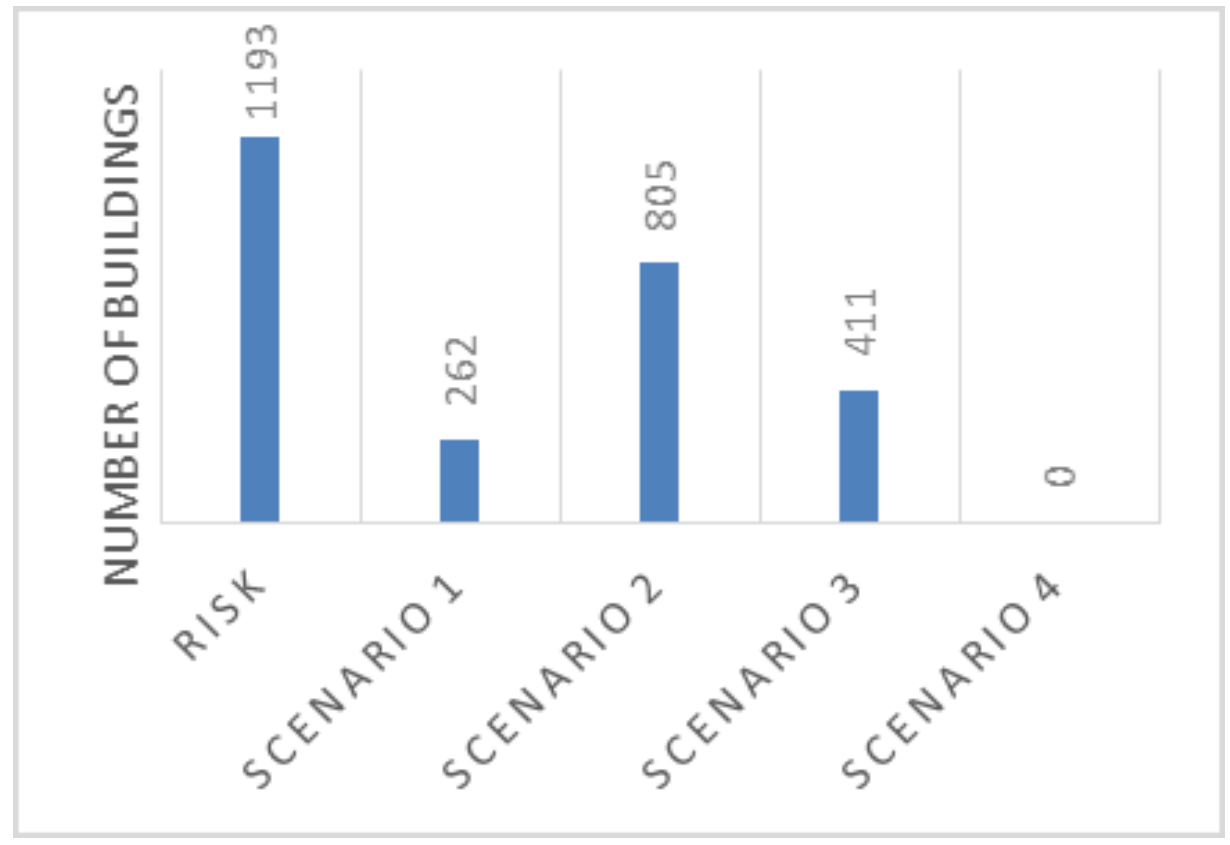

This study seeks to explore fire mitigation scenarios in densely populated settlements and also learn the lesson to be potentially and further applied elsewhere in Indonesia. The area of study, RWs 01-04, mostly consists of buildings with a Medium Risk of catching fire. This classification is relative towards the study area, meaning that risk classification within Sukahaji cannot be compared with other areas as they will have specific sources of hazards and vulnerabilities. Based on the analysis it is known that mitigation through optimizing local human capacity can be a primary alternative in handling fire risks within the area of study. Overall, Sukahaji is considered to have medium-high population density (Rianta, 2007), which means that optimizing local capacity can be a primary choice in handling fire risks within medium-high density populated settlements.

In case of capacity variable (C), optimizing capacity can be realized by providing more water hydrants or other sources of water available during the event of a fire. Furthermore, widening of roads is correspondingly essential for fire trucks accessibility to incident locations since densely populated settlements usually have narrow roads. In case of fire, it hampers fire extinguishing efforts and delays the safety of the surrounding environment.

Coburn et al. (1994) stated that five types of basic measures can be utilized in mitigation planning programs such as engineering and construction measures, physical planning measures, economic measures, institutional and management measures, and community action. From the previous mitigation scenarios, only engineering (relocating sources of hazards, road widening, etc.) and construction measures (replacing combustible materials with fire resistant ones) were applied. Community participation and early warning systems are other interventions that can be done. Community participation is an important 
component that should be utilized in reducing fire risk. In order for communities to actively participate in risk reduction, providing adequate information including its dissemination is imperative. Community based mitigation efforts should be integrated with all levels of society (schools, government officials, and other groups) (Duncanson et al., 2002). This has to do so that the community understands important things (to do list) during an emergency. Training, counseling, as well as evacuation simulations during a fictitious fire are several important activities in community-based mitigation efforts.

In addition, Sukahaji can additionally install a fire alarm as a fire mitigation effort. Installing smokedetecting fire alarms is an easy and effective method that can serve as an early warning system (Duncanson et al., 2002). Installing fire alarms in fire prone areas can increase community alertness and preparedness. If the warning systems go off, the locals can act quickly and subdue the fire before it spreads even further.

Physical planning measures are a form of mitigation planning that can be applied in disaster prone areas. In the context of the Indonesian urban fires, detailed plans (RDTR) and building layouts (RTBL) should be referred as documents governing these kinds of physical planning. As it has been discussed before, a primary alternative for mitigation is optimizing capacity (supplying sources of water and widening roads); thus this needs to be included in RDTRs and RTBLs. This can be done by supplying more water hydrants and other sources of water. Evacuation routes can also fit as additional elements in RDTRs/RTBLs as community-based mitigation efforts.

\section{CONCLUSION}

This study explores fire mitigation scenarios in densely populated settlements and has contributed to the limited literature on fire mitigation in Indonesia, especially that of urban fires. The results produced some mitigation scenarios such as intervention on the risk component as it can reduce the overall risk within Sukahaji, Bandung, potentially applied elsewhere in Indonesia. Optimizing capacity as a mitigation measure can be a primary alternative in handling fire hazards in areas with medium-high population density. Furthermore, an early warning system is discovered as an important factor in mitigation efforts. Therefore, it should be taken into account to optimize the risk reduction efforts in fire-prone areas. It promotes the involvement of community-based approach utilizing the local and existing resources within the community. Furthermore, this study can be integrated with the programs for fire mitigation by local governmental agencies, particularly the Fire Department (Dinas Pemadaman Kebakaran), Local Disaster Management Agency (Badan Penanggulangan Bencana Daerah; BPBD), and agencies related to the approval of building permits. Fire mitigation can be carried out at the earliest stage if the building density is taken into consideration.

\section{ACKNOWLEDGMENTS}

The authors are thankful for assistance and comments provided by Resilience Development Initiative (RDI) members, Elisabeth Rianawati, and Ramanditya Wimbardana.

\section{REFERENCES}

Bandung Central Bureau of Statistics. (2009). Bandung in Figures 2009. Bandung.

Barnwell, C., et al. (2005). Urban wildfire exposure modeling in the municipality of Anchorage, Alaska. In ESRI User Conference.

Coburn, A. W., et al. (1994). Mitigasi Bencana $2^{\text {nd }}$ ed. Program Pelatihan Manajemen Bencana, UNDP.

Cova, T. J. (1999). GIS in emergency management. Geographical Information Systems, 2, 845-858.

Duncanson, M., et al. (2002). Socioeconomic deprivation and fatal unintentional domestic fire incidents in New Zealand 1993-1998. Fire Safety Journal, 37(2), 165-179. http://doi.org/10.1016/s03797112(01)00033-9

Dwijayanti, F. (2008). Mitigasi Bencana Kebakaran di Permukiman Padat Kecamatan Bojongloa Kaler (Studi Kasus : Kelurahan Babakan Asih dan Kelurahan Jamika). Institut Teknologi Bandung. Retrieved from http://digilib.itb.ac.id/files/disk1/673/jbptitbpp-gdl-fajaresthy-33603-1-2008ta-r.pdf

Huang, K. (2009). Population and building factors that impact residential fire rates in large US cities.

IFRC. (2010). World disaster report. Retrieved from http://www.ifrc.org/Global/Publications/disasters/ WDR/WDR2010-full.pdf 
Indonesian Government. (2007). Law no 24/2007 Disaster Management.

Mantra, I. B. G. W. (2005). Kajian Penanggulangan Bahaya Kebakaran Pada Perumahan (Suatu Kajian Pendahuluan di Perumahan Sarijadi Bandung). Jurnal Permukiman Natah, 3(1), 24-33.

Moga, J. (2002). Disaster mitigation planning: the growth of local partnerships for disaster reduction. In Regional Workshop on Best Practices in Disaster Mitigation--Lessons Learned from the Asian Urban Disaster Mitigation Program and other Initiatives (pp. 24-26).

Prathama, F. P. (2011). Persepsi Risiko dan Kesiapsiagaan Penduduk Dalam Menghadapi Bahaya Kebakaran di Permukiman Padat (Studi Kasus: Kelurahan Sukahaji, Kota Bandung). Institut Teknologi Bandung.

Rianta, E. (2007). Pemetaan Risiko Bermacam Bahaya LIngkungan di Kelurahan Kampung Melayu, Cipinang Besar Utara dan Penjaringan Provinsi DKI Jakarta. Jakarta.

Sagala, S., et al. (2014). Perilaku dan Kesiapsiagaan Terkait Kebakaran pada Penghuni Permukiman Padat Kota Bandung. Forum Geografi, 28(1), 1-20.

Suprapto. (2008). Tinjauan Eksistensi Standar-Standar Proteksi Kebakaran dan Penerapannya dalam Mendukung Implementasi Peraturan Keselamatan Bangunan. Bandung.

Tarigan, A. K. M., et al. (2016). Bandung City, Indonesia. Cities, 50, 100-110.

Wahyudi, A. (2004). Identifikasi Tingkat Risiko Kebakaran Menggunakan SIG (Studi Kasus: Kota Bandung). Institut Teknologi Bandung.

Xin, J., \& Huang, C. (2013). Fire risk analysis of residential buildings based on scenario clusters and its application in fire risk management. Fire Safety Journal, 62, 72-78.

Zhou, B. (2013). Analysis of fire hazards of billboards on exterior walls of buildings and fire control safety countermeasures. Procedia Engineering, 52, 693-696. 